\title{
Expression of Concern: Synthesis, structural, optical, morphological and magnetic characterization of copper substituted nickel ferrite $\left(\mathrm{Cu}_{x} \mathrm{Ni}_{1-x} \mathrm{Fe}_{2} \mathrm{O}_{4}\right)$ through co-precipitation method
}

\author{
Abdelmajid Lassoued ${ }^{1,2} \cdot$ Mohamed Saber Lassoued $^{1,3} \cdot$ Fabienne Karolak $^{2} \cdot$ Santiago García-Granda $^{3}$. \\ Brahim Dkhil $^{2}$. Salah Ammar ${ }^{1}$. Abdellatif Gadri ${ }^{1}$
}

Published online: 8 May 2020

(c) Springer Science+Business Media, LLC, part of Springer Nature 2020

The Editor-in-Chief is issuing an editorial expression of concern regarding the article [1]. While the article presents novel information regarding chemical co-precipitation-based synthesis and characterization, the Editor-in-Chief is concerned regarding the amount of overlap with the articles [2, $3]$. None of the authors have responded to any correspondence from the editor or publisher about this overlap or the Editorial Expression of Concern.

\section{References}

1. A. Lassoued, M.S. Lassoued, F. Karolak et al., Synthesis, structural, optical, morphological and magnetic characterization of copper substituted nickel ferrite $\left(\mathrm{Cu}_{\mathrm{x}} \mathrm{Ni}_{1-\mathrm{x}} \mathrm{Fe}_{2} \mathrm{O}_{4}\right)$ through coprecipitation method. J. Mater. Sci. 28, 18480-18488 (2017). https://doi.org/10.1007/s10854-017-7795-4

2. A. Lassoued, B. Dkhil, A. Gadri et al., Control of the shape and size of iron oxide $\left(\mathrm{a}-\mathrm{Fe}_{2} \mathrm{O}_{3}\right)$ nanoparticles synthesized through

The original article can be found online at https://doi.org/10.1007/ s10854-017-7795-4.

Abdelmajid Lassoued

abdelmajid.lassoued@yahoo.fr

1 Unité de Recherche Electrochimie, Matériaux et Environnement UREME (UR17ES45), Faculté des Sciences de Gabès, Université de Gabès, Cité Erriadh, 6072 Gabès, Tunisia

2 Laboratory Structures, Properties and Modeling of Solids, Ecole Centrale Paris, CNRS-UMR8580, Grande Voie des Vignes, 92295 Chatenay-Malabry Cedex, France

3 Department of Physical and Analytical Chemistry, University of Oviedo-CINN, 33006 Oviedo, Spain the chemical precipitation method. Results Phys. 7, 3007-3015 (2017). https://doi.org/10.1016/j.rinp.2017.07.066

3. A. Lassoued, M.S. Lassoued, B. Dkhil et al., Synthesis, structural, optical and morphological characterization of hematite through the precipitation method: effect of varying the nature of the base. J. Mol. Struct. 1141, 99-106 (2017). https://doi.org/10.1016/j. molstruc.2017.03.077

Publisher's Note Springer Nature remains neutral with regard to jurisdictional claims in published maps and institutional affiliations. 